\title{
Migration of $\mathrm{Cr}_{2} \mathrm{O}_{7}^{2-}$ and Butanone in Soil and Groundwater System After the Tianjin Port 8.12 Explosion
}

\author{
Liyan Liu ${ }^{1} \cdot$ Shaopan Liang ${ }^{1} \cdot$ Hongchen Liu $^{1} \cdot$ Wei Tan ${ }^{1} \cdot$ Guorui Zhu ${ }^{1}$
}

Received: 1 February 2018 / Revised: 8 March 2018 / Accepted: 12 March 2018 / Published online: 19 April 2018

(c) The Author(s) 2018

\begin{abstract}
After the Tianjin Port 8.12 explosion, an enormous amount of potassium dichromate $\left(\mathrm{K}_{2} \mathrm{Cr}_{2} \mathrm{O}_{7}\right)$ and butanone $\left(\mathrm{CH}_{3} \mathrm{COCH}_{2} \mathrm{CH}_{3}\right)$ leaked into the coastal soil-groundwater system, which potentially threatened the environment and human health. Determining the transport process of hazards is necessary to establish guidelines for remediating the contaminated area. This work aims to investigate the migration of potassium dichromate and butanone in the coastal soil-groundwater system through a coupling unsaturated-saturated numerical model, incorporating the HYDRUS model into the MODFLOW/ MT3D model. In the unsaturated zone, two-dimensional HYDRUS model was applied, and its recharge flux at the bottom boundary was utilized as the input of MODFLOW/MT3D model in the saturated zone. Results showed that $\mathrm{Cr}_{2} \mathrm{O}_{7}^{2-}$ migrated much faster than butanone in the unsaturated zone and reached the water table in about 1 year. In comparison, butanone was unlikely to enter the aquifer even 5 years later with a migration depth of about $2.2 \mathrm{~m}$. Driven by groundwater, the $\mathrm{Cr}_{2} \mathrm{O}_{7}^{2-}$ that entered the aquifer migrated about $161 \mathrm{~m}$ toward southeast 5 years later. In the saturated zone, the contamination plume covered mainly the southeast area due to the groundwater flow direction.
\end{abstract}

Keywords Potassium dichromate · Butanone $\cdot$ HYDRUS $\cdot$ MODFLOW $\cdot$ Coastal soil-groundwater system · Tianjin Port $8 \cdot 12$ explosion

\section{Introduction}

On August 12, 2015, a fire erupted in the arrival area of the hazardous goods warehouse of Ruihai Company in Binhai New District of Tianjin, China [1]. A subsequent investigation discovered approximately 129 types of chemicals, including 1300 metric tons of ammonium nitrate and potassium nitrate, 500 metric tons of sodium metal and magnesium metal, 43.4 tons of potassium dichromate, 315.8 tons of butanone, and hundreds of tons of organic compounds stored in the warehouse. The incident led to the pollution in the local area and threatened human health after some of the chemicals leaked into the soil-water system.

Hazards, such as nitrate, heavy metallic salt, and various toxic organic compounds [2], which were likely to bring about significant casualties and loss of property once they leaked into the soil and groundwater, highlighted the

Guorui Zhu

zhuguorui@tju.edu.cn

1 School of Chemical Engineering and Technology, Tianjin University, Tianjin 300350, China severity of this explosion accident. Potassium dichromate is a toxic and carcinogenic chemical that is classified as primary carcinogen by the International Agency for Research on Cancer. It displays stronger cytotoxicity and mouse acute toxicity than does trivalent chromium [3]. Butanone is irritating to the eyes, nose, larynx, and mucous membrane, and it leads to the death of aquatic organisms [4].

Efforts have been made to better understand the hazard transport in various unsaturated or saturated conditions. Li et al. [5] researched methyl tert-butyl ether (MTBE) dissolution in saturated porous media to obtain MTBE dissolution data with different groundwater velocities, initial MTBE saturation, and grain size of porous medium. Dev et al. [6] discussed the potentiality of using anaerobic packed-bed bioreactor for the treatment of acid mine drainage. Multiple process parameters, such as $\mathrm{pH}$, hydraulic retention time, concentration of marine waste extract, total organic carbon, and sulfate, were optimized together using Taguchi design. The study also established the future scope for developing an efficient treatment process for sulfate and metal-rich mine wastewater on a large scale. 
Kim et al. proposed a new approach for integrating the quasi-distributed watershed model called SWAT with the fully distributed groundwater model MODFLOW [7]. The verified model demonstrated that an integrated SWAT-MODFLOW is capable of simulating the spatial-temporal distribution of groundwater recharge rates, aquifer evapotranspiration, and groundwater levels. Kuznetsov et al. presented a new approach for a numerical scheme for 3D variably saturated flow using the quasi 3D Richards equation and finite-difference scheme [8]. Computationally, the quasi-3D code was more efficient by an order of 10-300\%, while being accurate with respect to the benchmark fully $3 \mathrm{D}$ variable saturation code, when the capillary fringe was considered.

Some accident investigations have been conducted to identify human and organizational factors. Zhou et al. developed a modified version of the Human Factors Analysis and Classification System (HFACS), namely HFACS-Hazardous Chemicals, to identify the human factors involved in Chinese HCAs [9]. Zhou et al. selected the Tianjin 8.12 accident as an investigation case to present a simple and effective compound model in view of the advantages of different cause analysis models [10]. Most previous studies focused on the facts and lessons related to the accident, but not on the transport process of specific chemicals entering the soil-groundwater system.

This work aims to investigate the migration of potassium dichromate and butanone in the coastal soil-groundwater system of Binhai through a coupling unsaturated-saturated numerical model by incorporating the HYDRUS model into the MODFLOW/MT3D model. The soil properties were tested, and the area hydraulic conditions were explored. The verified numerical models were used to explore the substances' migration distance and boundaries during a period of time. On the basis of the results, a migration boundary was proposed for delimiting contaminated zones. The obtained migration results are expected to be useful in instructing environment remediation in similar accidents.

\section{Materials and Methods}

\section{Research Area}

The explosion site (39.2N 117.4E) is located in Tanggu of Binhai, China (Fig. 1). It is situated $2.7 \mathrm{~km}$ away from the coastline in the east and about $0.3 \mathrm{~km}$ away from Binhai Road in the west. As a result of floodplain, the upper soil is dredger filled, consisting of fine-grained sediment [11, 12]. The elevation of the ground surface is $2-3 \mathrm{~m}$ above the mean sea level, and the aquifer table is located about $5 \mathrm{~m}$ below the soil surface. Binhai has a temperate monsoon climate, an annual average temperature of $7.5-12.3{ }^{\circ} \mathrm{C}$, and an average annual precipitation of about $645 \mathrm{~mm}$ in the coastal region.
Fig. 1 Location of the explosion site

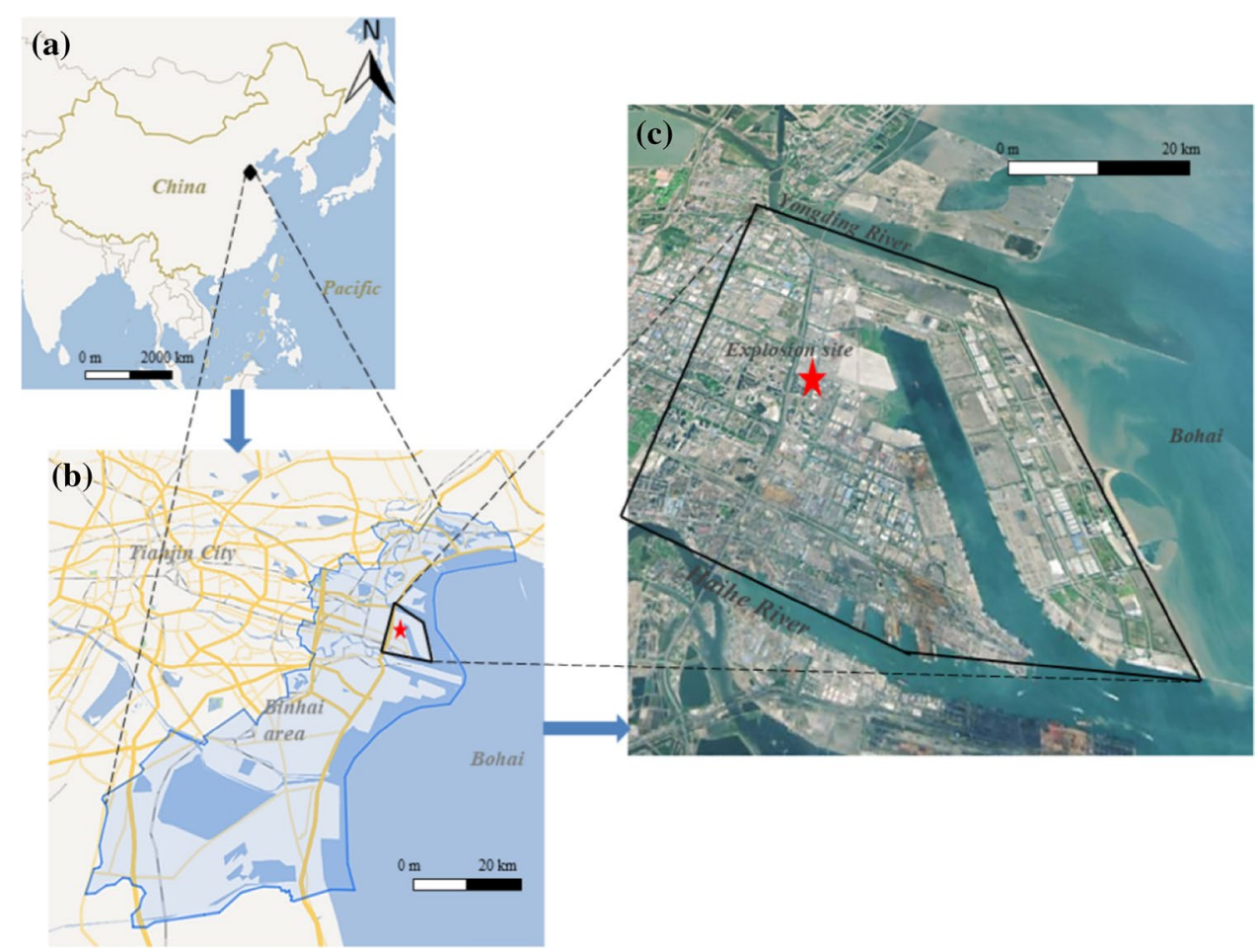




\section{Properties of Soil}

The soil profile information obtained from geology borehole-G2 is listed in Table 1.

To determine the soil properties, soil samples were collected from a few points near the explosion site. The soil was naturally air-dried, crushed, and sieved through the American Society for Testing and Materials standard sieves. Soil particles, which are finer than $2 \mathrm{~mm}$, were applied in the test experiments. A number of soil sample properties, such as mechanical composition, $\mathrm{pH}$, total salt content, organic matter, and hydraulic conductivity, were evaluated in this study. The physical and chemical properties are presented in Table 2.

\section{Hazardous Chemicals}

The physical and chemical properties of potassium dichromate [13] and butanone [14] are listed in Table 3.

\section{Numerical Simulation}

After leaking into the soil from the surface, the transport process of hazards consisted of infiltration through the vadose zone and migration in the groundwater after reaching the water table. Given the great difference between the two zones, establishing an integrated numerical model is of great significance to investigate water and solute transport in the whole soil-water system [15]. One-dimensional or two-dimensional HYDRUS models have been proven to be efficient methods to describe the process in an unsaturated zone, considering the thickness and significant hydraulic gradient of such a zone [16]. In the saturated zone, MODFLOW and MT3D packages are applied to describe water and solute transport in a three-dimensional model, respectively. Being fully incorporated into the MODFLOW program, the HYDRUS package provides MODFLOW with recharge fluxes at the water table, while MODFLOW provides HYDRUS with the position of the groundwater table that is used as the bottom boundary condition in the package

Table 1 Geology borehole-G2 description

\begin{tabular}{llll}
\hline Layer & Depth $(\mathrm{m})$ & Lithology & Description \\
\hline 1 & $0-2.8$ & Backfill & Derived from late Holocene tidal flat alluvium \\
2 & $2.8-20.6$ & Fine silt & Dark gray sludge silt, soft plastic-like, partially silt, and clayey silt interbedded \\
3 & $20.6-31.0$ & Clay silt & $\begin{array}{c}\text { Yellow-brown silt, fine sand, clayey silt. The upper part is mainly fine silt; the lower part silt and clay silt } \\
\text { are intermixed }\end{array}$ \\
4 & $31.0-39.0$ & Silty clay & Dark gray silt, clay, silt; common carbon debris cuttings and shellfish based on smooth blue clams and clams \\
5 & $39.0-53.8$ & Fine sand & The turbid yellow-brown, gray-yellow-brown silt, silty sand, loose accumulation, no bedding \\
6 & $53.8-70.9$ & Silty clay, clay & $\begin{array}{c}\text { Gray-yellow-brown, dark gray silt, fine sand, clayey silt; central gray clay silt and the lower part of the fine } \\
\text { sand content increased }\end{array}$ \\
7 & $70.9-80.3$ & Silty clay & Yellow-brown, olive gray silty clay, fine sand; the top of the dense block has calcareous concretions \\
\hline
\end{tabular}

Engineering geological borehole G2 (E1173736, N390356) was obtained from the Tianjin Geological Information Museum

Table 2 Physical and chemical properties of soil

\begin{tabular}{llllllllll}
\hline Clay $(\%)$ & Silt $(\%)$ & Sand $(\%)$ & Bulk density $\left(\mathrm{g} / \mathrm{cm}^{3}\right)$ & $\mathrm{OM}(\mathrm{g} / \mathrm{kg})$ & $\mathrm{pH}$ & Salt content $(\%)$ & Total N $(\mathrm{mg} / \mathrm{kg})$ & $\mathrm{CEC}(\mathrm{cmol} / \mathrm{kg})$ & $K_{\mathrm{s}}(\mathrm{m} / \mathrm{day})$ \\
\hline 23.5 & 65.0 & 11.5 & $1.21-1.53$ & 13.92 & 8.38 & 2.28 & 20.07 & 8.61 & $0.35-0.58$ \\
\hline
\end{tabular}

$O M$ organic matter, $C E C$ cation exchange capacity

Table 3 Properties of potassium dichromate and butanone

\begin{tabular}{llllllll}
\hline Chemicals & Chemical formula & Appearance & Melting point $\left({ }^{\circ} \mathrm{C}\right)$ & $\begin{array}{l}\text { Boiling } \\
\text { point } \\
\left({ }^{\circ} \mathrm{C}\right)\end{array}$ & Toxicity & Water solubility & Leakage $(\mathrm{t})$ \\
\hline $\begin{array}{l}\text { Potassium dichro- } \\
\text { mate }\end{array}$ & $\mathrm{K}_{2} \mathrm{Cr}_{2} \mathrm{O}_{7}$ & $\begin{array}{c}\text { Orange-red } \\
\text { triclinic plate } \\
\text { crystal }\end{array}$ & 398 & 500 & $\begin{array}{c}\text { Toxic and carcino- } \\
\text { genic }\end{array}$ & $\begin{array}{c}\text { Slightly soluble in } \\
\text { cold water; solu- } \\
\text { ble in hot water }\end{array}$ & $\begin{array}{c}43.4 \\
\text { Slightly soluble }\end{array}$ \\
Butanone & $\mathrm{CH}_{3} \mathrm{COCH}_{2} \mathrm{CH}_{3}$ & Colorless liquid & -85.9 & 79.6 & Low toxicity & S15.8 \\
\hline
\end{tabular}


[17]. The schematic of the coupling model is presented in Fig. 2.

\section{Mathematical Model}

HYDRUS-2D numerically solves the Richards equation for saturated-unsaturated water flow and Fickian-based advection-dispersion equations for heat and solute transport [18].

MODFLOW and MT3D are modules integrated into the Groundwater Modeling System, which is a comprehensive graphical user environment for performing groundwater simulations. MT3D is a modular three-dimensional transport model for the simulation of advection, dispersion, and chemical reactions of dissolved constituents and is used in conjunction with MODFLOW in flow and transport simulation [19].

\section{Water Flow Equation}

The relation between water flux and soil pressure head in both unsaturated and saturated zones is governed by the Richards equation, which has the following form [20]:

$q=-k(\theta)\left(\frac{\partial h}{\partial x}+\frac{\partial h}{\partial y}+\frac{\partial h}{\partial z}+1\right)$

where $q$ is the water flux, $\mathrm{L} / \mathrm{T} ; h$ is the soil pressure head, $\mathrm{L} ; k(\theta)$ is the hydraulic conductivity as a function of the soil water content, $\mathrm{L} / \mathrm{T}$; and $\theta$ is the volumetric water content, $\mathrm{L}^{3} / \mathrm{L}^{3}$.

Van Genuchten model [21] is widely used to describe the relationship between soil pressure head $h$ and water content $\theta$, which is defined by the following equation:

$\theta=\theta_{\mathrm{r}}+\frac{\theta_{\mathrm{s}}-\theta_{\mathrm{r}}}{\left[1+\left(\alpha h_{\mathrm{s}}\right)^{n}\right]^{m}}$,

where $\theta_{\mathrm{r}}$ is the residual water content, $\mathrm{L}^{3} / \mathrm{L}^{3} ; \theta_{\mathrm{s}}$ is the saturated water content, $\mathrm{L}^{3} / \mathrm{L}^{3} ; h_{\mathrm{s}}$ is the pressure head $\left(h_{\mathrm{s}}=|h|\right.$ for $h<0$ and $h_{\mathrm{s}}=0$ for $h \geq 0$ ), L; and $\alpha, n$, and $m$ are parameters $(m=1-1 / n)$.

The water flow is defined by the following equation [22]:

$\frac{\partial}{\partial x}\left(K_{x} \frac{\partial h}{\partial x}\right)+\frac{\partial}{\partial y}\left(K_{y} \frac{\partial h}{\partial y}\right)+\frac{\partial}{\partial z}\left(K_{z} \frac{\partial h}{\partial z}\right)+q_{\mathrm{s}}=S_{\mathrm{s}} \frac{\partial h}{\partial t}$,

where $K_{x}, K_{y}$, and $K_{z}$ are the hydraulic conductivity in the direction of the $x, y$, and $z$ coordinates, respectively, $\mathrm{L} / \mathrm{T} ; q_{\mathrm{s}}$ is the sinks/sources, $1 / \mathrm{T}$; and $S_{\mathrm{s}}$ is the specific storage of the porous material, $1 / \mathrm{L}$.

\section{Solute Transport Equation}

The solute transport equation is defined by the following advection-dispersion equation [22]:

$\frac{\partial(\theta R C)}{\partial t}=\frac{\partial}{\partial x_{i}}\left(\theta D_{i j} \frac{\partial C}{\partial x_{j}}\right)-\frac{\partial}{\partial x_{i}}\left(q_{i} C\right)+q_{\mathrm{s}} C_{\mathrm{s}}-\lambda_{1} \theta C-\lambda_{2} \rho_{\mathrm{b}} \bar{C}$,

where $C$ is the liquid-phase concentration, $\mathrm{M} / \mathrm{L}^{3} ; \bar{C}$ is the sorbed concentration, $\mathrm{M} / \mathrm{L}^{3} ; q_{\mathrm{s}}$ is the source or sink term in the water flow equation, $1 / \mathrm{T} ; C_{\mathrm{s}}$ is the concentration of source or sink term, $\mathrm{M} / \mathrm{L}^{3} ; \lambda_{1}$ and $\lambda_{2}$ are the liquid-phase reaction rate coefficient and adsorption phase reaction rate coefficient, $1 / \mathrm{T}$, respectively; $D$ is the dispersion coefficient, $\mathrm{L}^{2} / \mathrm{T} ; \rho_{\mathrm{b}}$ is the bulk density; and $\mathrm{M} / \mathrm{L}^{3}$; and $R$ is the retardation factor.

\section{Results and Discussion}

\section{Unsaturated Simulation}

\section{Numerical Model}

The model area is presented in Fig. 3. The lateral flow is very weak in the unsaturated zone. Thus, the $2 \mathrm{D}$ model in
Fig. 2 Schematic of the coupling model

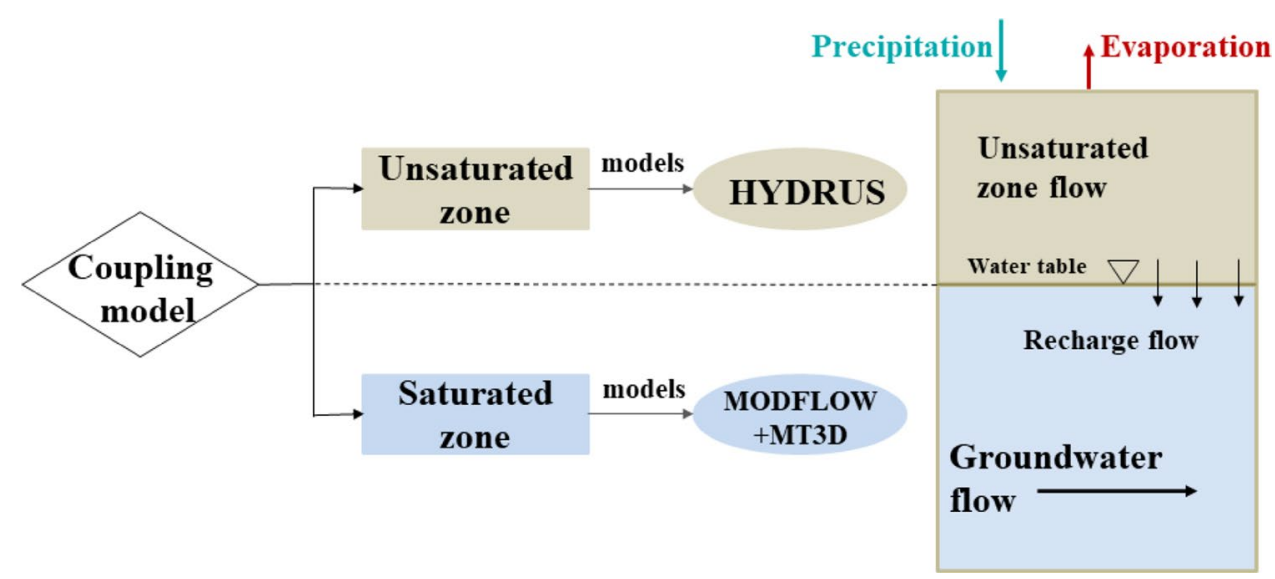


Fig. 3 Position of two-dimensional profile at the accident site (a)

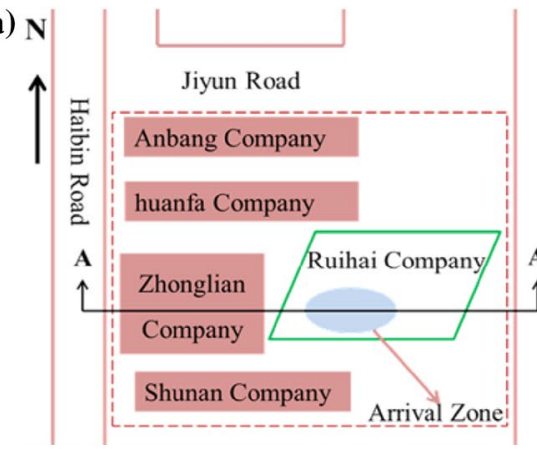

(b)

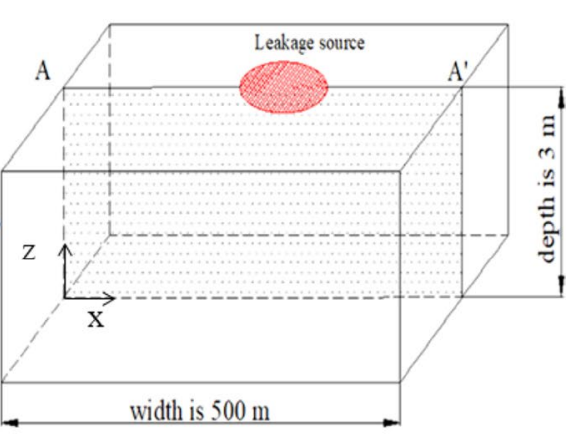

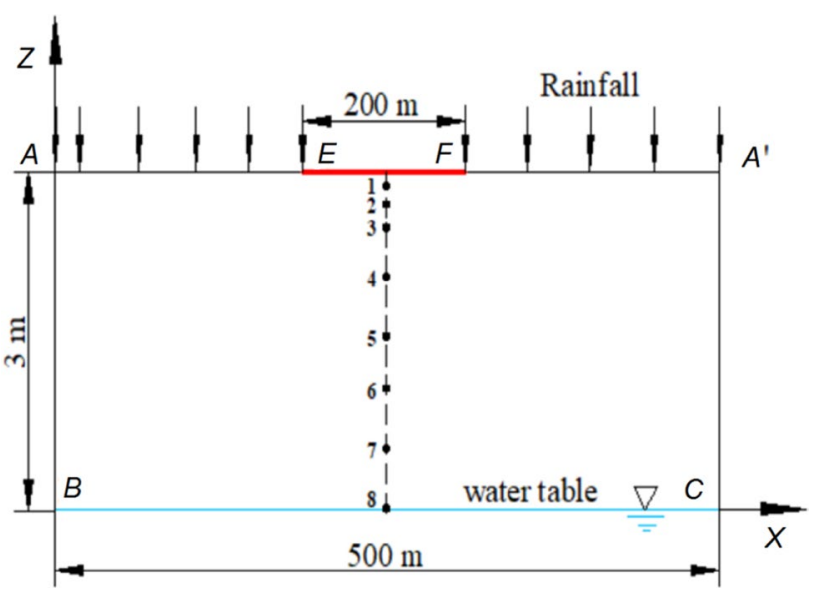

Fig. 4 Contaminant transport model in the unsaturated zone

the $x$ and $z$ directions is capable of simulating hazard migration without considering the process in the $y$ direction [23]. The two-dimensional vertical section is $3 \mathrm{~m}$ in depth [24] from the soil surface to the water table and about $500 \mathrm{~m}$ in width from west Haibin Road to east Yuejin Road.

The two-dimensional finite-element contaminant transport model is presented in Fig. 4. The solute transport boundary conditions are as follows: $E F$ is the pollutant discharge boundary condition, and $A B, B C$, and $A^{\prime} C$ are the no-flux boundary conditions. The water flow boundary conditions are as follows: $A A^{\prime}$ is the atmospheric boundary condition, and $B C$ is the constant head boundary. At the initial time, the pressure head above the water table obtained through linear interpolation was negative [25-27], and the initial contamination concentrations were zero. The rainfall data, as obtained from the Tianjin Water Affairs Bureau, are presented in Fig. 5. The model parameters are listed in Table 4.

The model was verified through a field experiment conducted at a site located about $800 \mathrm{~m}$ near the explosion site because the actual explosion site was not available. The hydrogeological properties of the experiment site were similar to those of the explosion site. The experiment site is shown in Fig. 6.

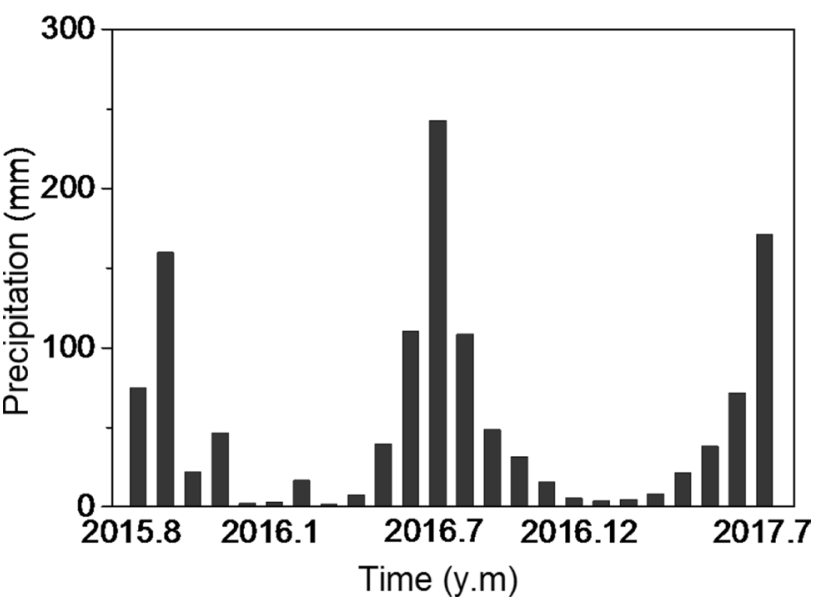

Fig. 5 Rainfall data of the latest 2 years

Table 4 Parameters of water flow and solute transport

\begin{tabular}{|c|c|c|c|c|c|}
\hline No. & $\begin{array}{l}\text { Water flow } \\
\text { parameter }\end{array}$ & Value & $\begin{array}{l}\text { Solute } \\
\text { transport } \\
\text { parameter }\end{array}$ & $\begin{array}{l}\text { Potassium } \\
\text { dichromate }\end{array}$ & Butanone \\
\hline 1 & $\theta_{\mathrm{r}}$ & 0.11 & $\rho_{\mathrm{b}}\left(\mathrm{g} / \mathrm{cm}^{3}\right)$ & 1.5 & 1.5 \\
\hline 2 & $\theta_{\mathrm{s}}$ & 0.45 & $D_{\mathrm{L}}(\mathrm{m})$ & 0.0015 & 0.01 \\
\hline 3 & $K_{\mathrm{s}}(\mathrm{cm} / \mathrm{min})$ & 0.017 & $D_{\mathrm{T}}(\mathrm{m})$ & 0.001 & 0.02 \\
\hline 4 & $\alpha$ & 0.015 & $D_{\mathrm{w}}\left(\mathrm{m}^{2} /\right.$ day $)$ & 0.01 & 0.1 \\
\hline 5 & $n$ & 1.56 & $K_{\mathrm{d}}\left(\mathrm{m}^{3} / \mathrm{g}\right)$ & 0.1 & 0.4 \\
\hline 6 & $l$ & 0.5 & & & \\
\hline
\end{tabular}

$K_{\mathrm{s}}$ is the saturated hydraulic conductivity, $\mathrm{L} / \mathrm{L} ; l$ is a pore-connectivity parameter; $D_{\mathrm{L}}$ is the longitudinal dispersivity, $\mathrm{L} ; D_{\mathrm{T}}$ is the transverse dispersivity, $\mathrm{L} ; D_{\mathrm{w}}$ is the molecular diffusion coefficient in free water, $\mathrm{L}^{2} / \mathrm{T} ; K_{\mathrm{d}}$ is the adsorption isotherm coefficient, $\mathrm{L}^{3} / \mathrm{M}$

The prepared potassium chloride solution was leaked on the soil surface for a duration of $6 \mathrm{~h}$. After the solution leakage, soil solution samples were taken every $24 \mathrm{~h}$ at depths of 1.0, 2.0, and $2.5 \mathrm{~m}$ under the leakage surface until the concentration reached a steady state. The $\mathrm{K}^{+}$concentration of the samples was tested.

A comparison between the experimental and simulation results at the monitoring points is presented in Fig. 7. 


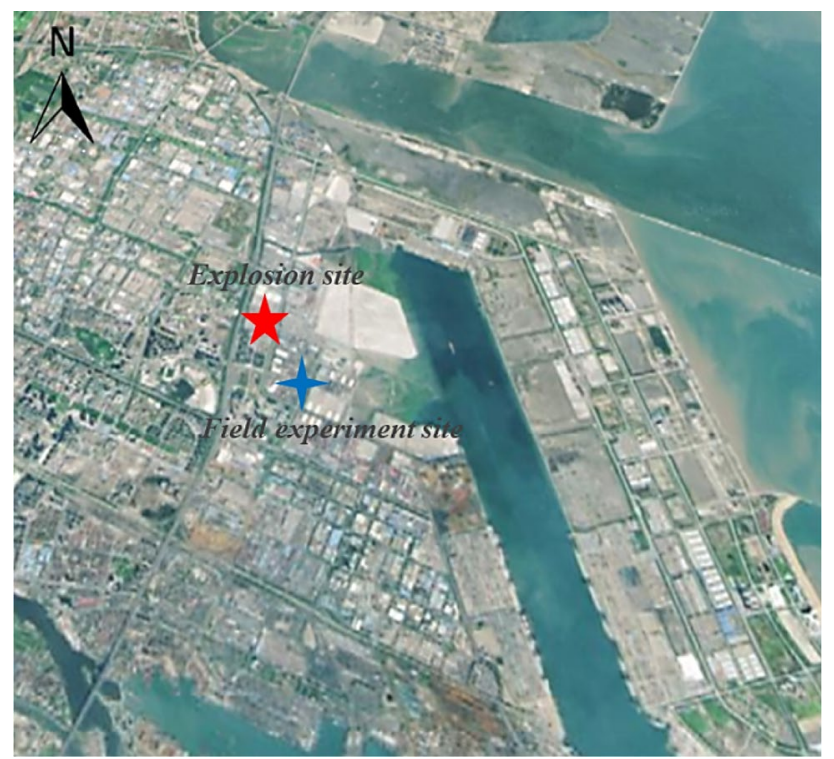

Fig. 6 Field experiment site

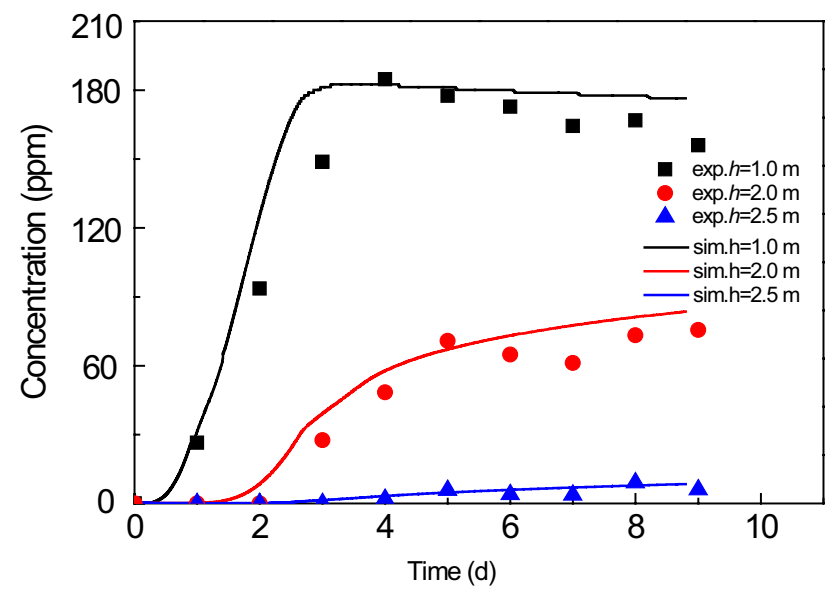

Fig. 7 BTCs of experiments and simulation results at monitoring points

Judging from the $\mathrm{K}^{+}$breakthrough curve (BTC), the variation trend of the simulation is approximately consistent with that of the experiment. However, the errors were up to about $30 \%$ at some stages, and the experiment transport rate was higher, which may be due to the strong driving force in filling the solution and the preferential flow [28-30] in the soil. According to the comparison results, the model was assumed to be reliable in simulation research.

\section{Analysis on Potassium Dichromate}

The simulation result of $\mathrm{Cr}_{2} \mathrm{O}_{7}^{2-}$ transport over 730 days is presented in Fig. 8, and the BTCs at the monitoring points are presented in Fig. 9. Judging from the contamination plume, $\mathrm{Cr}_{2} \mathrm{O}_{7}^{2-}$ reached a depth of $1.2 \mathrm{~m}$ at the beginning of 2 months because of the heavy rain in this period. After 6 months, the migration depth was up to $1.7 \mathrm{~m}$, and the concentration in liquid phase began to decrease because of soil adsorption. In the horizontal direction, the migration process was very weak compared with that in the vertical direction as a result of weak lateral flow [31] in the vadose zone.

In Fig. 9, BTCs showed that the variation trends of concentration vary from the depths and time stages. At depths of $0.1,0.3$, and $0.5 \mathrm{~m}$, the concentration reached peak values at 80,130 , and 210 days, respectively. The solute migration rate was in line with the trend of precipitation intensity. $\mathrm{Cr}_{2} \mathrm{O}_{7}^{2-}$ reached the water table at a depth of $3 \mathrm{~m}$ after about 330 days. According to the mass balance information, after 2 years, about $12 \%$ of the total $\mathrm{Cr}_{2} \mathrm{O}_{7}^{2-}$ entered the aquifer, while the rest remained in the soil at a depth of $3 \mathrm{~m}$. The $\mathrm{Cr}_{2} \mathrm{O}_{7}^{2-}$ entering the aquifer transported in the groundwater system [32], which is different from the unsaturated zone.

\section{Analysis on Butanone}

The simulation results of butanone migration are presented in Fig. 10. The transport rate of butanone was much slower than that of $\mathrm{Cr}_{2} \mathrm{O}_{7}^{2-}$. Two months after the leakage, butanone reached a depth of only about $0.35 \mathrm{~m}$ and then reached a depth of about $0.67 \mathrm{~m}$ after 6 months. Obviously, the largest difference in the transport processes of butanone and $\mathrm{Cr}_{2} \mathrm{O}_{7}^{2-}$ was that in 2 years, butanone reached a depth of $1.5 \mathrm{~m}$ instead of the water table. To predict the migration distance of butanone in the long term, a simulation of a 5 -year period was conducted. Compared with the distance in the first 2 years, butanone transported about $0.7 \mathrm{~m}$ farther in another 3 years, but still did not reach the aquifer.

According to the BTCs in Fig. 11, in the last 2 years, the concentration at the monitoring points changed smoothly without significant fluctuations and showed low sensitivity to precipitation. At depths of 0.1 and $0.3 \mathrm{~m}$, the concentrations reached peak values at about 120 and 480 days, respectively. Under the same conditions, the soil adsorption to butanone was much stronger [33] than that to $\mathrm{Cr}_{2} \mathrm{O}_{7}^{2-}$. In addition, the advection process in water was much weaker due to the low water solubility of the soil [34]. At a conservative estimate, a small amount of butanone would reach the water table due to the removal of the unsaturated zone.

\section{Saturated Simulation}

\section{Numerical Model}

Considering the significant water flow in the saturated zone, a three-dimensional model was built to track the solute transport process after entering the aquifer. To simplify the simulation, the bottom boundary flux of the HYDRUS model 
Fig. 8 Contamination plume of $\mathrm{Cr}_{2} \mathrm{O}_{7}^{2-}$ in the unsaturated zone (a)

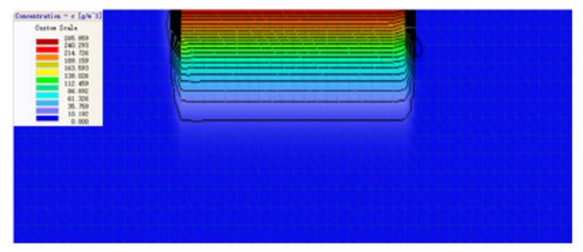

2 months

(c)

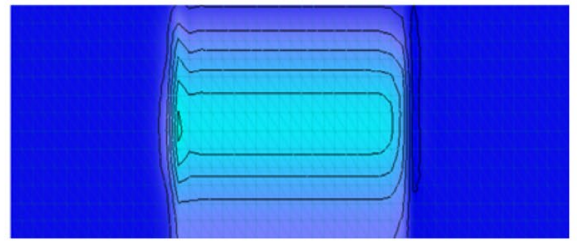

12 months (b)

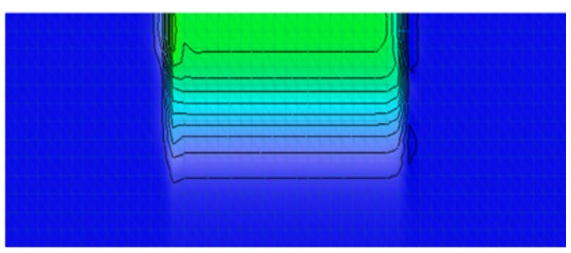

6 months

(d)

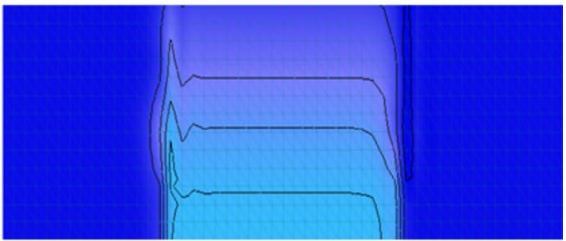

24 months

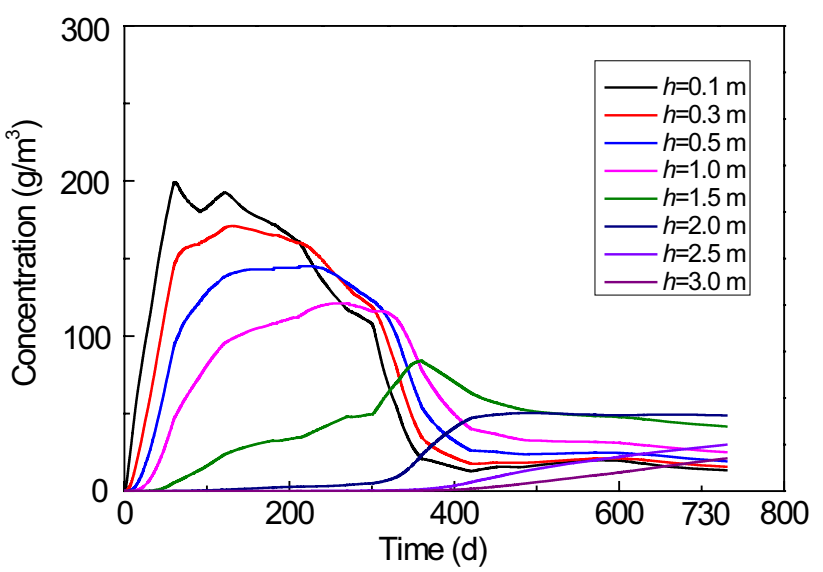

was incorporated as the recharge flux of the MODFLOW model. The model boundary and the MODFLOW model are presented in Fig. 12.

The water flow boundary conditions are as follows: the east, north, and south are constant head boundary conditions; Nanfeng Road in the west is the specified flow boundary conditions; and the area surface is the recharge boundary conditions. The solute transport boundary conditions are as follows: all the boundaries are no-flux boundary conditions. The background concentrations of hazards are assumed to be zero in the research area. The flow simulation results computed by MODFLOW are read by MT3D and utilized as the flow field for the transport portion of the simulation [35].

Fig. 9 BTCs of $\mathrm{Cr}_{2} \mathrm{O}_{7}^{2-}$ at the monitoring points

Fig. 10 Contamination plume of butanone in the unsaturated zone (a)

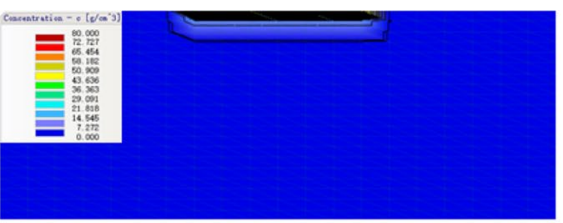

2 months

(c)

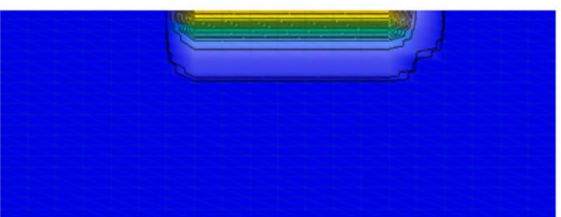

12 months

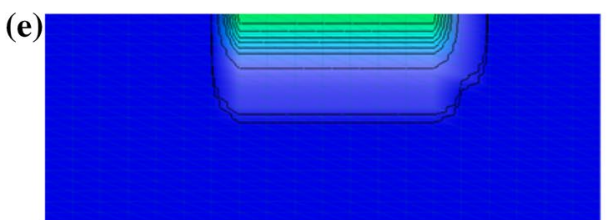

36 months (b)

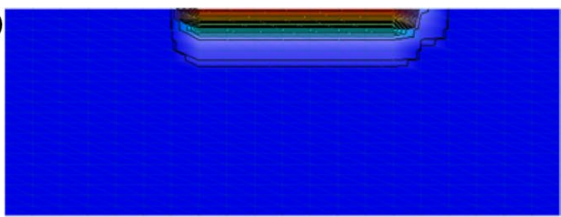

6 months

(d)

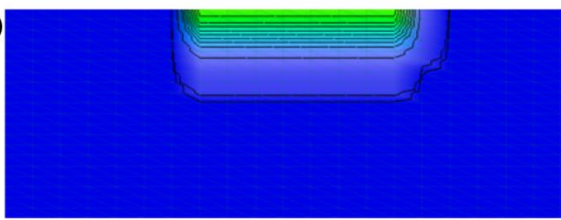

24 months

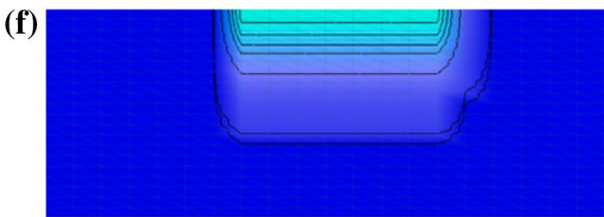

60 months 


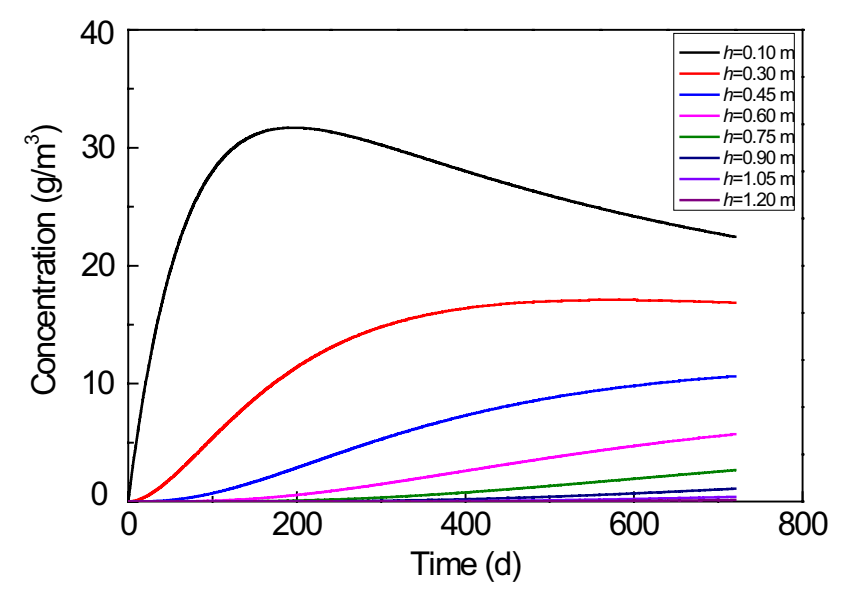

Fig. 11 BTCs of butanone at the monitoring points

\section{Analysis on Potassium Dichromate}

From the flow field presented in Fig. 12, we could determine that the water level in the west was higher than that in the east coast. The flow direction of the groundwater in the area is generally from the northwest to the southeast at a low flow rate.

The migration results of $\mathrm{Cr}_{2} \mathrm{O}_{7}^{2-}$ in the saturated zone are shown in Fig. 13. First, judging from the contamination plume, $\mathrm{Cr}_{2} \mathrm{O}_{7}^{2-}$ had a greater tendency to migrate in the east and south directions than in the west and north directions. Two years after the leakage, the farthest migration horizontal distance of $\mathrm{Cr}_{2} \mathrm{O}_{7}^{2-}$ was about $73 \mathrm{~m}$ in south. To predict the potential migration distance of $\mathrm{Cr}_{2} \mathrm{O}_{7}^{2-}$ in the long term, a simulation of 3-, 4-, and 5-year periods was conducted. The contaminant reached a horizontal distance of about 105, 127, and $161 \mathrm{~m}$ in groundwater, respectively. According to the concentration distribution, the contaminant tended to accumulate at the section under the leakage source area and reached a farther distance with a low concentration.

On the basis of the above results, the unsaturated soil zone played a vital role in the removal of contaminants that infiltrated from the soil surface. Organic matter showed different transport properties from that of inorganic matter in the soil-water system. Butanone transported much more slowly than $\mathrm{Cr}_{2} \mathrm{O}_{7}^{2-}$ in unsaturated soil without reaching the aquifer in 5 years. In comparison, a portion of $\mathrm{Cr}_{2} \mathrm{O}_{7}^{2-}$ reached the aquifer and transported with the groundwater flow to a much farther distance, especially in the horizontal direction. Considering the harm posed by $\mathrm{Cr}_{2} \mathrm{O}_{7}^{2-}$ to the environment, measures should be taken immediately to clean up the contamination in the potential covered areas and the migration boundary [36, 37]. Different renovation strategies for various contaminants should be applied because of their different migration rates and contamination plumes [38].

\section{Conclusions}

An estimation of the coupling two-dimensional HYDRUS model and three-dimensional MODFLOW/MT3D model to address contamination mobility in the coastal soil-groundwater system of Binhai showed that $\mathrm{Cr}_{2} \mathrm{O}_{7}^{2-}$ and butanone displayed different migration properties under the same conditions. $\mathrm{Cr}_{2} \mathrm{O}_{7}^{2-}$ migrated relatively faster in the unsaturated zone than did butanone and reached the water table in about 1 year. In comparison, butanone reached a depth of only $1.5 \mathrm{~m}$ after 2 years and was unlikely to enter the aquifer even 5 years later with a migration distance of about $2.2 \mathrm{~m}$, according to the simulation prediction. Driven by underground water, the $\mathrm{Cr}_{2} \mathrm{O}_{7}^{2-}$ that entered the aquifer migrated about $161 \mathrm{~m}$ toward the southeast. The contamination plume covered mainly the area in the southeast direction because of the groundwater flow direction. Measures should be taken
Fig. 12 MODFLOW model conducted on the research area

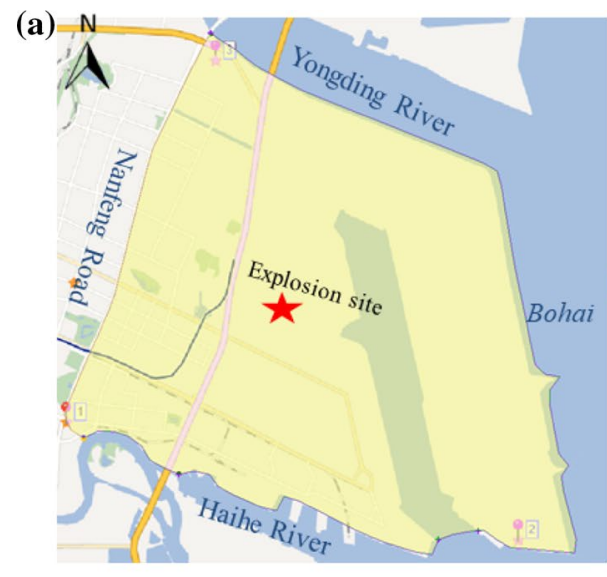

Model area

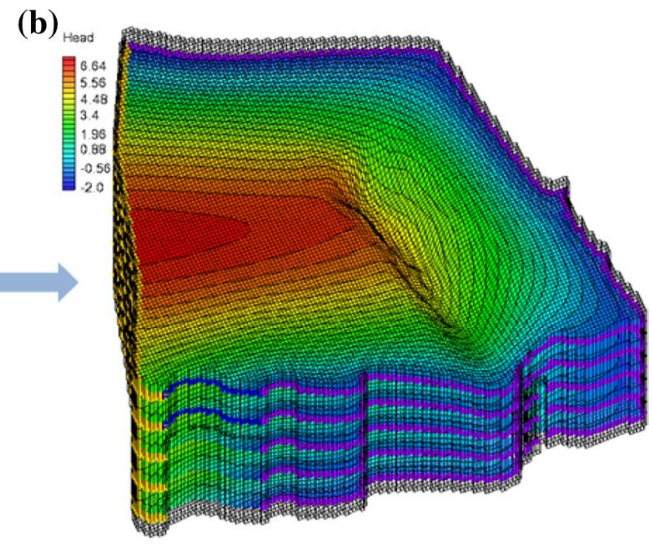

MODFLOW model 
Fig. 13 Contamination plume of $\mathrm{Cr}_{2} \mathrm{O}_{7}^{2-}$ in the saturated zone (a)

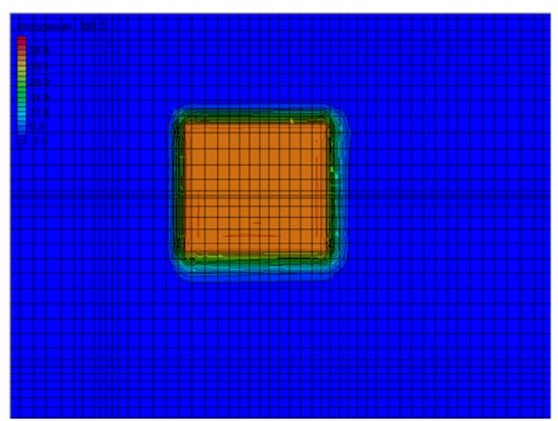

2 years

(c)

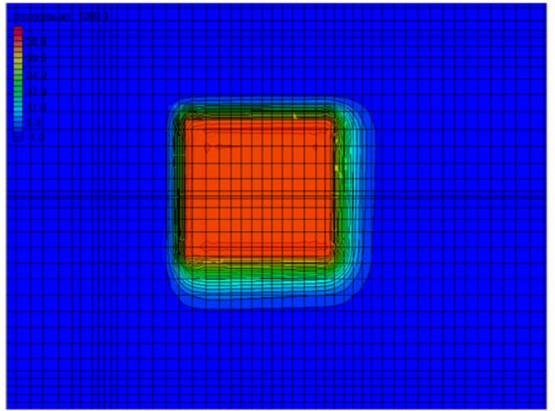

4 years (b)

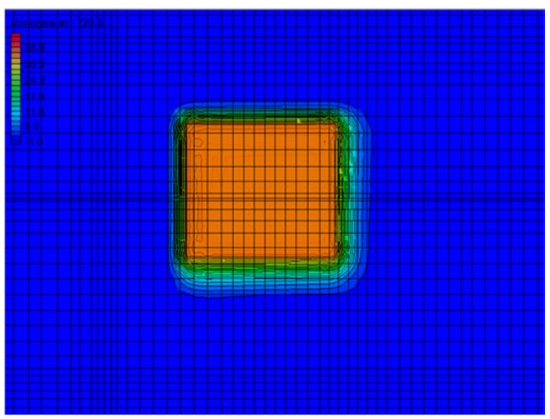

3 years

(d)

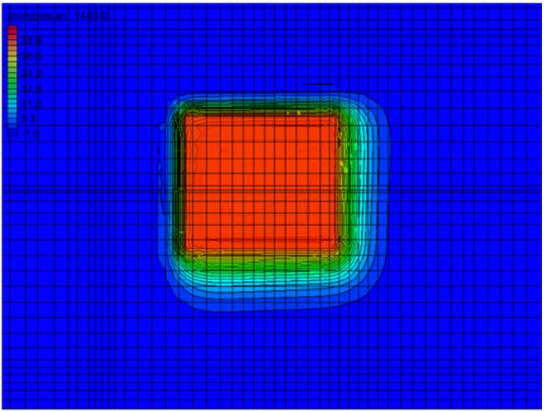

5 years immediately after leakage to clean up the contamination in the upper soil in case of arrival at the water table.

Acknowledgements This research was supported by the National Natural Science Foundation of China (No. 21656001). The authors also wish to express appreciation to Yidong Wang, associate professor of the Tianjin Key Laboratory of Water Resources and Environment, Tianjin Normal University, for his assistance on the experiments.

Open Access This article is distributed under the terms of the Creative Commons Attribution 4.0 International License (http://creativeco mmons.org/licenses/by/4.0/), which permits unrestricted use, distribution, and reproduction in any medium, provided you give appropriate credit to the original author(s) and the source, provide a link to the Creative Commons license, and indicate if changes were made.

\section{References}

1. Huang P, Zhang J (2015) Facts related to August 12, 2015 explosion accident in Tianjin, China. Process Saf Prog 34(4):313-314

2. Fu G, Wang J, Yan M (2016) Anatomy of Tianjin Port fire and explosion: process and causes. Process Saf Prog 35(3):216-220

3. Ma HZ, Sheng HZ, Qin AP et al (2003) Comparative study on toxicities of potassium dichromate and chromium chloride. Carcinog Teratog Mutagen 15(3):171-173 (in Chinese)

4. Parker Jr WON (1999) Chemical transformations on a weakly acidic catalyst studied by ${ }^{15} \mathrm{~N}$ NMR: butanone oxime on silicalite-1. Magn Reson Chem 37(6):433-436

5. Li H, Zhao L, Gao X et al (2015) Experimental investigation of methyl tert-butyl ether dissolution in saturated porous media. Chin J Chem Eng 23(10):1685-1690
6. Dev S, Roy S, Bhattacharya J (2017) Optimization of the operation of packed bed bioreactor to improve the sulfate and metal removal from acid mine drainage. J Environ Manag 200:135-144

7. Kim NW, Chung IM, Won YS et al (2008) Development and application of the integrated SWAT-MODFLOW model. J Hydrol 356(1-2):1-16

8. Kuznetsov M, Yakirevich A, Pachepsky YA et al (2012) Quasi 3D modeling of water flow in vadose zone and groundwater. J Hydrol 450-451:140-149

9. Zhou L, Fu G, Xue Y (2017) Human and organizational factors in Chinese hazardous chemical accidents: a case study of the ' 8.12 ' Tianjin Port fire and explosion using the HFACS-HC. Int J Occup Saf Ergon 56:1-12

10. Zhou AT, Fan LP (2017) A new insight into the accident investigation: a case study of Tianjin Port fire and explosion in China. Process Saf Prog 36(4):362-367

11. Su XP, Wang Q, Song J (2012) Physical and chemical characteristics of high clay content dredger fill in different regions. In: ICETCE ' 12 proceedings of the 2012 second international conference on electric technology and civil engineering, Washington, DC

12. Li XJ, Wang Q, Yan $\mathrm{H}$ et al (2013) Research on engineering geological properties of dredger fill in Tianjin Qingfang economic region. Appl Mech Mater 405-408:147-150

13. Liu GQ, Ma LX, Liu J (2002) Handbook of chemistry property data. Inorganic volume. Chemical Industry Press, Beijing (in Chinese)

14. Liu GQ, Ma LX, Liu J (2002) Handbook of chemical property data. Organic volume. Chemical Industry Press, Beijing (in Chinese)

15. Connell LD (2007) Simple models for subsurface solute transport that combine unsaturated and saturated zone pathways. J Hydrol 332(3-4):361-373

16. Gumula-Kawęcka A, Szymkiewicz A, Angulo-Jaramillo R et al (2017) Numerical simulation of infiltration and groundwater recharge using the HYDRUS for MODFLOW package and the 
BEST model of soil hydraulic properties. Geophys Res Abstr 19:EGU2017-1514

17. Twarakavi NKC, Simunek J, Seo S (2008) Evaluating interactions between groundwater and vadose zone using the HYDRUS-based flow package for MODFLOW. Vadose Zone J 7(7):757-768

18. Seo HS, Simůnek J, Poeter EP (2007) Documentation of the HYDRUS package for MODFLOW-2000, the US geological survey modular ground-water model. GWMI 2007-01 International Ground Water Modeling Center, Colorado School of Mines, Golden

19. Prommer H, Barry DA, Zheng C (2003) MODFLOW/MT3DMSbased reactive multicomponent transport modeling. Ground Water 41(2):247-257

20. Busscher W (1980) Simulation of field water use and crop yield. Soil Sci 129(3):193

21. Van Genuchten MT (1980) A closed-form equation for predicting the hydraulic conductivity of unsaturated soils. Soil Sci Soc Am J 44:892-898

22. Zheng CM, Bennett GD (2009) Applied contaminant transport modelling. Wiley, Hoboken

23. Zhu Y (2013) Study on quasi-3D water flow and solute transport model in regional scales and its applications. Dissertation, Wuhan University, Wuhan (in Chinese)

24. Kong QY (2012) Study on the engineering properties of improved hydraulic filled ground in Tianjin Binhai Area. Dissertation, Tianjin University, Tianjin (in Chinese)

25. Liu Y, Kuang X, Jiao JJ et al (2015) Numerical study of variabledensity flow and transport in unsaturated-saturated porous media. J Contam Hydrol 182:117-130

26. Dong W, Wang Q, Zhou B et al (2013) A simple model for the transport of soil-dissolved chemicals in runoff by raindrop. CATENA 101:129-135

27. Xu M (2008) Experiment study on soil-water characteristic curve in unsaturated zone. Dissertation, Chang' an University, Xi' an (in Chinese)

28. Bundt M, Widmer F, Pesaro M et al (2001) Preferential flow paths: biological 'hot spots' in soils. Soil Biol Biochem 33(6):729-738
29. Gazis C, Feng X (2004) A stable isotope study of soil water: evidence for mixing and preferential flow paths. Geoderma 119(1-2):97-111

30. Šimůnek J, Jarvis NJ, Van Genuchten MT et al (2003) Review and comparison of models for describing non-equilibrium and preferential flow and transport in the vadose zone. J Hydrol 272(1-4):14-35

31. Yang JF, Liu SP, Zhang DK et al (2001) Study on the water movement in soil with shallow water table. Irrig Drain 20(3):25-28 (in Chinese)

32. El Yaouti F, El Mandour A, Khattach D et al (2008) Modelling groundwater flow and advective contaminant transport in the Bou-Areg unconfined aquifer (NE Morocco). J Hydro-environ Res 2:192-209

33. Wang Z, Zhu XX, Xiao LW et al (2010) Sorption of toluene and trichloroethylene to vadose zone soils at different depths. Ecol Environ Sci 19(12):2892-2896 (in Chinese)

34. Li H, Li XG, Huang GQ et al (2007) Modeling the migration of soluble methanol in unsaturated soil zone. Pedosphere 17(3):366-372

35. Borgia A, Cattaneo L, Marconi D et al (2011) Using a MODFLOW grid, generated with GMS, to solve a transport problem with TOUGH 2 in complex geological environments: the intertidal deposits of the Venetian Lagoon. Comput Geosci 37(6):783-790

36. Yeh $\mathrm{CH}$, Lin $\mathrm{CW}, \mathrm{Wu} \mathrm{CH}$ (2010) A permeable reactive barrier for the bioremediation of BTEX-contaminated groundwater: microbial community distribution and removal efficiencies. J Hazard Mater 178(1-3):74-80

37. Ji ZY, Yuan JS, Li XG (2007) Removal of ammonium from wastewater using calcium form clinoptilolite. J Hazard Mater 141(3):483-488

38. Liu SJ, Jiang B, Huang GQ et al (2006) Laboratory column study for remediation of MTBE-contaminated groundwater using a biological two-layer permeable barrier. Water Res 40(18):3401-3408 